\title{
Australian Journal of \\ Effect of bunch protection material and bagging time on the yield of 'Nanica' banana and chilling control
}

\author{
Juliana Domingues Lima ${ }^{1}{ }^{*}$, Eric Watzke Engelking ${ }^{1}$, Danilo Eduardo Rozane ${ }^{1}$, Eduardo Nardini Gomes ${ }^{1}$, \\ Silvia Helena Modenese Gorla da Silva ${ }^{1}$, Ricardo Alfredo Kluge ${ }^{2}$
}

\author{
${ }^{1}$ São Paulo State University, UNESP, Registro, São Paulo, Brazil \\ ${ }^{2}$ University of São Paulo, USP, Department of Biological Sciences, Piracicaba, Brazil
}

\author{
*Corresponding author: juliana.d.lima@unesp.br
}

\begin{abstract}
The bagging of banana bunch can control chilling injury $(\mathrm{Cl})$ in the field, which causes browning of banana peel. The purpose of this study was to evaluate the effect of changing the bunch protection material and bagging time on the yield of 'Nanica' banana (AAA) and the occurrence of $\mathrm{Cl}$. The experiment was conducted in Jacupiranga, SP, Brazil. The experimental design was completely randomized design arranged in a $2 \times 2 \times 6$ factorial scheme with eight replicates, two bunch formation periods (autumn-winter and winter-spring), two bagging times (early, before the opening of bracts, and late, after complete opening) and six treatments. Treatments were polyethylene bags with different thickness (blue bags of $3 \mu$ in thickness and black bags of 6,8 and $10 \mu$ in thickness combined with white non-woven fabric, black bag of $10 \mu$ in thickness combined with blue polyethylene bag $5 \mu$ in thickness impregnated with insecticide) and non-bagged banana. The change of sunlight transmission with black polyethylene bags of different thickness promoted a small increase in fruit peel temperature $\left(0.14\right.$ to $\left.0.57^{\circ} \mathrm{C}\right)$ on colder days $\left(8.72^{\circ} \mathrm{C}\right)$, reduced $\mathrm{Cl}$ index and improved peel brightness $\left(L^{*}\right)$ and $h^{\circ}$ (hue angle), although it did not affect bunch mass. However, in late winter, sunburn increased fruit losses. Sunlight transmission in fruit peel was correlated with $\mathrm{Cl}$ index $\left(r=0.92^{*}\right), L^{*}\left(r=-0.77^{*}\right)$ and phenols $\left(\mathrm{r}=0.85^{*}\right)$. Despite not controlling $\mathrm{Cl}$, early bagging is recommended for increasing peel $\mathrm{L}^{*}$.
\end{abstract}

Keywords: Musa spp., cold protection, black polyethylene, thickness, sunlight transmission, peel browning, phenols.

Abbreviations: Cl_chilling injury; T_temperature; Tmin_minimum temperature; ST_sunlight transmission; Tmax_maximum; NB_non-bagged; Pol blue 3+WFN_blue transparent polyethylene $3 \mu+$ white non-woven fabric $3 \mu$; Pol black $6+$ WFN_black polyethylene $6 \mu+$ white non-woven fabric $3 \mu$; Pol black $8+$ WFN black polyethylene $8 \mu+$ white non-woven fabric $3 \mu$; Pol black

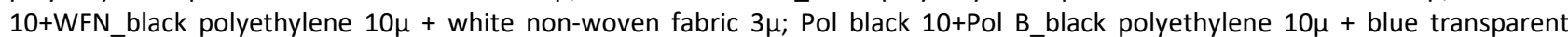
polyethylene $5 \mu$ impregnated with insecticide; $\mathrm{Cl}$ index_chilling injury index; BM_bunch mass; PHF_period between flowering and harvest; $\mathrm{CL} a$ _chlorophyll $a$; $\mathrm{CL} b$ _chlorophyll $b$; CAR_carotenoids; PHE_total phenols; $\mathrm{a}^{*}$ _coordinated $\mathrm{a}^{*}$; $\mathrm{b}^{*}$ _coordinated $\mathrm{b}^{*}$; $\mathrm{L}^{*}$ _brightness; $\mathrm{C}^{*}{ }_{-}$chromaticity; $\mathrm{h}^{\circ}{ }_{-}$hue angle.

\section{Introduction}

Banana is a plant of tropical origin (Robinson and Saúco, 2012) that is grown commercially from the equator to the subtropics and its fruits are widely consumed all around the world (Fortescue et al., 2011).

Under sufficient water supplies, banana growth and yield are mainly determined by temperature (Robinson and Saúco, 2012). Moderate temperature $\left(20-30^{\circ} \mathrm{C}\right)$ is an essential requirement for appropriate vegetative growth, fruit development and maximum yield (Simmonds, 1962). Chilling (temperatures lower than $20^{\circ} \mathrm{C}$ ) is one of the factors that limits the establishment of banana plantations at certain latitudes, and has an impact on the growth and development of plants, yield and fruit quality (Zapata et al., 2015).

Banana fruit are highly susceptible to chilling injury $(\mathrm{Cl})$, whose symptoms can occur at approximately $12^{\circ} \mathrm{C}$ (Chen et al., 2008) and causes losses of up to $50 \%$ in the yield (Zapata et al., 2015). Mild symptoms, commonly caused by field $\mathrm{Cl}$ include only peel browning of sub-epidermal peel tissue (Chen et al., 2008), but strongly affect the visual quality and marketability (Hashim et al., 2012)

Banana bunch bagging is a physical protection method, which improves the peel coloration of fruit and reducing blemishes, the incidence of disease and insect pest, mechanical damage, sunburn, agrochemical residues, bird damage (Santosh et al., 2017)

Bunch bagging had been also reported to increase temperature of fruit microenvironment and the visual quality (Jullien et al., 2008; Sarkar, 2014; Kutinyu et al., 2014; Pathak et al., 2017b; Santosh et al., 2017) and can prevent $\mathrm{Cl}$ in field (Harvey, 2006).

Blue polyethylene is the material mostly used for this purpose (Robinson and Saúco, 2012). However, other materials may be used, such as non-woven fabric, paper, canvas, drill cloth, sisal, hessian, polylactic acid (Mustaffa and Kumar, 2012, Pathak et al., 2017, Santosh et al., 2017). 
Optical and thermal characteristics of bagging material vary in function of their chemical and physical properties, as well as radiative heat transfer process, which is different in each material (Al-Mahdouri et al., 2013). The color, thickness and layering can affect the thermal properties and the sunlight transmission.

The use of double-layer bagging material with a different color than the usual and thicker material has reduce field $\mathrm{Cl}$ and produced larger banana fruits in Tule, Australia (Harvey, 2006). Differences in temperature inside the bag due to color of polyethylene and presence or absence of perforation were able to reduce $\mathrm{Cl}$ in Mozambique, Africa (Kutinyu et al., 2014). However, in that region the minimum temperature did not exceed $11.8^{\circ} \mathrm{C}$. The use of black polyethylene in winter is a usual practice in China (Xu et al., 2011), promoting both absorb and re-emit radiation as thermal energy or long wavelength infrared (Lamont, 2017). The early bunch bagging (immediately after emergence of the inflorescence) was recommended by Mustaffa and Kumar (2012) to increase fruit length and reduce the time between flowering and harvest. However, there are no reports about its effect on fruit color and $\mathrm{Cl}$ prevention.

The bagging technology should be exploited for trapping heat inside solar energy and devices and/or suppressing the outside ambient convection. The purpose of this study was to evaluate the effect of changing the bunch protection material and bagging time on the yield of 'Nanica' banana (AAA) and the occurrence of $\mathrm{Cl}$.

\section{Results and Discussion}

\section{Effect of protection material on temperature of fruit peel/ surface}

On the coldest day, Tmin was very close for both bunch formation periods, averaging $8.72^{\circ} \mathrm{C}$ (Table 1). Under this condition, the treatments increased $\mathrm{T}$ between 1.19 and $1.96^{\circ} \mathrm{C}$. The non-bagged treatments (NB) were incapable to maintain the peel $\mathrm{T}$ higher than $12^{\circ} \mathrm{C}$, which is the limit for the occurrence of $\mathrm{Cl}$ in Cavendish banana (Chen et al., 2008, Hashim et al., 2012). The $T$ value detected on the peel surface reflected the combinations of materials (Table 2 ). In two-film-layers treatments, heat must first be transferred from the inner (WFN or Biflex ${ }^{\circledR}$ ) to the outer layer (polyethylene) of the bag before it is transferred to the atmosphere. Since it is very porous (Mangaraj et al. 2009), polypropylene (WFN) tends to have lower heat transfer compared to polyethylene (Biflex ${ }^{\circledR}$ ). Pol blue $3+$ WFN have been used by farmers, exhibiting the lowest thermal effect. Black polyethylene bags used in treatments were transparent, allowing sunlight transmission (ST) depending on thickness (Table 1). At the same time, bags created a "greenhouse" effect to capture the long wave radiation under the film surface. The increase in thickness also probably contributed to the reduction of heat loss by convection. This explains its greater impact on peel Tmin and Tmax.

The use of double layer polyethylene bags extended the ability to increase $T$ (Harvey, 2006), which confirmed with Pol black $10+$ Pol B (Table 1), which was designed to combine early thermal protection with the control of thrips. One hypothesis to explain the greater thermal effect of this treatment is the higher water condensation due to existence of small droplets on the inner surface of the black bag, which reduces transmission of long wave radiation and increases emission, while transmissivity to short wave radiation is almost unaffected (Lamont et al, 2017). Loss of energy by convection was prevented with the use of non-perforated black polyethylene bag.

On warm days, black polyethylene bag with greater thickness (low LT) excessively increases the air $T$ in both periods (Table 1 ) and caused sunburn. About $81.25 \%$ of bunches, pol black10 + Pol B caused sunburn on fruits of hand 1 and hand 2, against about 31.25\% in Pol black $10+$ WFN and $12.5 \%$ in Pol black $8+$ WFN and only on fruits of hand $1(p<0.05)$. The occurrence of sunburn may be directly associated with greater water condensation on the inner surface of the film.

The difference in the occurrence of sunburn between Pol black 10+WFN and Pol black10+Pol B $(p<0.05)$ can be related to the movement of water vapor generated by the fruit transpiration to the inner surface of the polyethylene bag. Biflex ${ }^{\circledR}$ has perforation that favors diffusion (Table 2), while WFN is continuous and has higher barrier to water vapor, compared to polyethylene (Mangaraj et al. 2009).

Alterations promoted a small increase in the fruit surface Tmin, which occurred at dawn, when there is no sunlight. In other studies with polyethylene, similar results were observed, with significant increases in air Tmax compared to the external environment, and slight increases Tmin (Rebouças et al., 2015), an effect attributed to the low capacity of polyethylene to retain long wavelength radiation. There was a difference of $20 \mathrm{~h}$ in stress $\mathrm{T}\left(<12^{\circ} \mathrm{C}\right)$ between bunch growth periods, whereas none of which showed temperature below $5^{\circ} \mathrm{C}$. This caused severe symptoms in fruits, less frequent in the region.

\section{Effect of protection material and bagging times on fruit yield}

There was no triple interaction for any of variables studied $(p<0.05)$. Bunches harvested in winter-spring showed higher $\mathrm{BM}, \mathrm{CL} a$ and $\mathrm{CAR}$ content and lower PHF and $\mathrm{Cl}$ index, when compared to those harvested in autumn-winter (Table 3) due to higher $T$ and lower cold stress hours (Table 1 ).

Bagging times did not affect any of the agronomic characteristics (BM and PHF), $\mathrm{Cl}$ index, content of pigments, and PHE of fruit peel (Table 3). However, Jullien et al. (2008) observed fruits of large diameter with early bagging compared with NB. This is a response attributed to the elevated $\mathrm{T}$ of about $2^{\circ} \mathrm{C}$ in the bag, which may have increased the cell division and fruit filling rates.

Protection materials did not influence BM, only PHF, which was extended in 9 days between Pol black 10 Pol B and NB (Table 3). This indicates that the photosynthetic activity of fruits might be influenced when fruit grows with low ST through of bag and that this effect overlapped the increase in $T$ (Table 1). Other treatments were not different. In north Queensland in Australia, bags with high LT increased bunch photosynthesis and improved fruit size (Harvey, 2006). However, in Costa Rica, polyethylene bags of different thicknesses did not influence BM and fruit size (Vargas-Calvo and Valle-Ruiz, 2011). Bagging materials affected $\mathrm{Cl}$ index, $\mathrm{CL}$ $a$ and CAR content (Table 3). NB and Pol blue 3+WFN exhibited higher $\mathrm{Cl}$ index (severe injury) when compared 
Table 1. Temperature $\left({ }^{\circ} \mathrm{C}\right)$ of the air in canopy and in the surface fruits/peel in function of protection material during colder and warmer day of the two periods of bunch formation.

\begin{tabular}{lccc}
\hline & \multicolumn{3}{c}{ Autumn-Winter } \\
\hline Canopy & Tmin & Tmin bag-Tmin NB & Tmin \\
NB & 8.70 & - & 31.37 \\
Pol blue 3+WFN & 9.19 & - & 28.86 \\
Pol black 6+WFN & 10.38 & 1.19 & 29.06 \\
Pol black 8+WFN & 10.52 & 1.33 & 33.03 \\
Pol black10+WFN & 10.60 & 1.41 & 34.65 \\
Pol black10+Pol B & 10.65 & 1.46 & 35.04 \\
& 10.76 & 1.57 & 40.46 \\
\hline & & & 5.79 \\
\hline Canopy & & & Winter-Spring \\
NB & Tmax & Tmax & 3.18 \\
Pol blue 3+WFN & 8.74 & & 39.08 \\
Pol black 6+WFN & 9.52 & & 43.08 \\
Pol black 8+WFN & 10.91 & 1.39 & 43.25 \\
Pol black10+WFN & 11.09 & 1.57 & 43.62 \\
Pol black10+Pol B & 11.27 & 1.75 & 44.75 \\
\hline
\end{tabular}

*Mean values obtained from two replicates of thermocouples. NB, non-bagged; Pol blue $3+$ WFN, blue transparent polyethylene $3 \mu+$ white non-woven fabric $3 \mu$; Pol black $6+$ WFN, black polyethylen $6 \mu+$ white non-woven fabric $3 \mu$; Pol black $8+$ WFN, black polyethylene $8 \mu+$ white non-woven fabric $3 \mu$; Pol black 10+WFN, black polyethylene $10 \mu+$ white non-woven fabric $3 \mu$; Pol black $10+$ Pol B, black polyethylene $10 \mu$ tblue transparent polyethylene $5 \mu$ impregnated with insecticide.Autumn-Winter: $28.52 \mathrm{~h}$ with $\mathrm{T}<12^{\circ} \mathrm{C}$ e $0 \mathrm{~T}<5^{\circ} \mathrm{C}$. Winter-Springer: $8.74 \mathrm{~h}$ with $\mathrm{T}<12^{\circ} \mathrm{C}$ e $0 \mathrm{~T}<5^{\circ} \mathrm{C}$.

Table 2. Characteristics of bunch bags (protective materials)

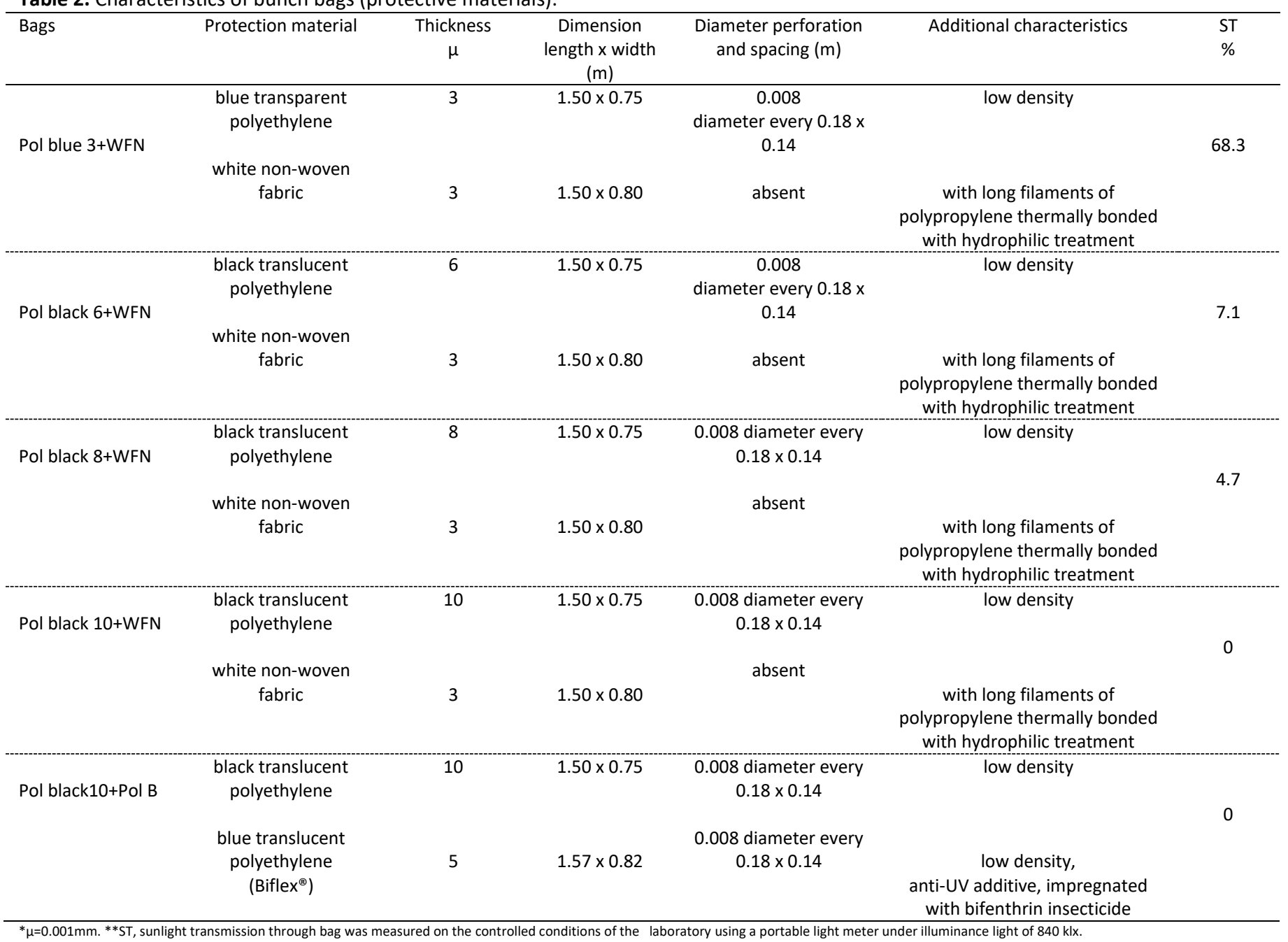

${ }^{*} \mu=0.001 \mathrm{~mm} .{ }^{* *} \mathrm{ST}$, sunlight transmission through bag was measured on the controlled conditions of the laboratory using a portable light meter under illuminance light of $840 \mathrm{klx}$. 
Table 3. Agronomic characteristics, chilling injury index, content of photosynthetic pigments and total phenols in the peel of green fruits of banana 'Nanica', in function to the period of formation of the bunch, bagging time and protection material.

\begin{tabular}{|c|c|c|c|c|c|c|c|}
\hline & $\begin{array}{l}\mathrm{BM} \\
\mathrm{kg}\end{array}$ & $\begin{array}{l}\text { PHF } \\
\text { day }\end{array}$ & $\mathrm{Cl}$ index & $\mathrm{CL} a$ & $\begin{array}{l}\mathrm{CL} b \\
\mu \mathrm{g} \mathrm{g}^{-1}\end{array}$ & CAR & $\begin{array}{l}\text { PHE } \\
\mathrm{mg} \mathrm{g}^{-1}\end{array}$ \\
\hline Autumn-Winter & $27.93 \mathrm{~B}$ & $142.88 \mathrm{~A}$ & $3.38 \mathrm{~A}$ & $7.40 \mathrm{~B}$ & 6.65 & $8.47 \mathrm{~B}$ & 1.40 \\
\hline Winter-Spring & $30.96 \mathrm{~A}$ & $113.42 \mathrm{~B}$ & $2.13 \mathrm{~B}$ & $11.50 \mathrm{~A}$ & 6.98 & $11.39 \mathrm{~A}$ & 1.37 \\
\hline vc (\%) & 19.52 & 128.15 & 7.75 & 12.22 & 24.44 & 17.14 & 9.63 \\
\hline $\mathrm{F}$ & $13.39 * *$ & $282.08^{* *}$ & $8.15^{* *}$ & $73.71^{* *}$ & $1.13^{\mathrm{ns}}$ & $83.65 * *$ & $2.25^{\mathrm{ns}}$ \\
\hline Late & 29.85 & 127.26 & 2.63 & 9.80 & 6.65 & 9.95 & 1.37 \\
\hline Early & 29.87 & 129.05 & 2.88 & 9.08 & 6.98 & 9.91 & 1.39 \\
\hline vc (\%) & 19.09 & 5.69 & 6.49 & 12.22 & 24.44 & 17.14 & 17.72 \\
\hline $\mathrm{F}$ & $0.03^{\mathrm{ns}}$ & $2.51^{\mathrm{ns}}$ & $2.14^{\mathrm{ns}}$ & $2.97^{\text {ns }}$ & $1.13^{\mathrm{ns}}$ & $0.02^{\mathrm{ns}}$ & $1.69^{\text {ns }}$ \\
\hline NB & 27.28 & $121.89 \mathrm{~B}$ & $4.00 \mathrm{~A}$ & $10.71 \mathrm{~A}$ & 6.97 & $11.72 \mathrm{~A}$ & $2.02 \mathrm{~A}$ \\
\hline Pol blue 3+WFN & 28.52 & $129.45 A B$ & $3.67 \mathrm{~A}$ & $10.52 \mathrm{AB}$ & 6.85 & $10.76 A B$ & $1.92 \mathrm{~A}$ \\
\hline Pol black $6+$ WFN & 30.96 & $129.06 \mathrm{AB}$ & $2.67 \mathrm{AB}$ & $10.12 \mathrm{ABC}$ & 7.03 & $10.08 \mathrm{BC}$ & $1.45 \mathrm{~B}$ \\
\hline Pol black 8+WFN & 30.40 & $127.65 \mathrm{AB}$ & $2.33 \mathrm{AB}$ & $8.61 \mathrm{ABC}$ & 6.87 & $9.74 \mathrm{BC}$ & $1.38 \mathrm{~B}$ \\
\hline Pol black $10+$ WFN & 30.39 & $130.21 \mathrm{AB}$ & $2.00 \mathrm{~B}$ & $8.05 \mathrm{CD}$ & 7.20 & $8.78 \mathrm{C}$ & $0.79 \mathrm{C}$ \\
\hline Pol black10+Pol B & 31.59 & $130.78 \mathrm{~A}$ & $2.00 \mathrm{~B}$ & $8.74 \mathrm{D}$ & 5.86 & $8.54 \mathrm{C}$ & $0.72 \mathrm{C}$ \\
\hline vc (\%) & 19.09 & 7.31 & 8.30 & 12.22 & 11.94 & 17.14 & 16.27 \\
\hline $\mathrm{F}$ & $1.51^{\mathrm{ns}}$ & $3.25 *$ & $9.78 * *$ & $4.60 * *$ & $1.13^{* *}$ & $9.07 * *$ & $10.14 * *$ \\
\hline
\end{tabular}

$\mathrm{BM}$, bunch mass; PHF, period between flowering and harvest; Cl index, chilling injury index; CL $a$, chlorophyll $a$; CL $b$, chlorophyll $b$; CAR, carotenoids; PHE, total phenols. NB, non-bagged; Pol blue $3+$ WFN, blue transparent polyethylene $3 \mu+$ white non-woven fabric $3 \mu$; Pol black $6+W F N$, black polyethylene $6 \mu+$ white non-woven fabric $3 \mu$; Pol black $8+$ WFN, black polyethylene $8 \mu+$ white nonwoven fabric $3 \mu$; Pol black $10+$ WFN, black polyethylene $10 \mu+$ white non-woven fabric $3 \mu$; Pol black 10+Pol B, black polyethylene $10 \mu+$ +blue transparent polyethylene $5 \mu$ impregnated with insecticide. Means followed by the same letters in the column did not differ from each other by the Tukey test $(p<0.05) .{ }^{*}, p<0.05 ;{ }^{* *}, p<0.01 ;{ }^{\text {NS }}$, not significant to F test $(p<0.05)$.

Table 4. Peel color components of fruits of banana 'Nanica' in function to the period of formation of the bunch, bagging time and protection material.

\begin{tabular}{|c|c|c|c|c|c|}
\hline & $\mathrm{L}^{*}$ & a* & $b^{*}$ & $\mathrm{C}^{*}$ & $\mathrm{~h}^{\circ}$ \\
\hline & \multicolumn{5}{|c|}{ Green fruit } \\
\hline Autumn-Winter & $57.90 \mathrm{~B}$ & -17.64 & 35.39 & $39.61 \mathrm{~B}$ & $116.47 \mathrm{~B}$ \\
\hline Winter-Spring & $59.69 \mathrm{~A}$ & -17.52 & 37.54 & $40.71 \mathrm{~A}$ & $117.61 \mathrm{~A}$ \\
\hline vc (\%) & 6.21 & 10.80 & 21.70 & 2.89 & 1.58 \\
\hline \multirow[t]{2}{*}{$\mathrm{F}$} & $6.77^{*}$ & $0.01^{\mathrm{ns}}$ & $2.11^{\mathrm{ns}}$ & $40.16^{* *}$ & $37.07 * *$ \\
\hline & \multicolumn{5}{|c|}{ Ripe fruit } \\
\hline Autumn-Winter & $66.76 \mathrm{~B}$ & 0.31 & 39.79 B & $39.83 \mathrm{~B}$ & 90.32 \\
\hline Winter-Spring & $71.15 \mathrm{~A}$ & 0.33 & 43.07 A & $43.14 \mathrm{~A}$ & 88.90 \\
\hline vc (\%) & 6.13 & 10.80 & 9.27 & 10.02 & 5.76 \\
\hline \multirow[t]{2}{*}{$\mathrm{F}$} & $30.69 *$ & $2.46^{\mathrm{ns}}$ & $20.79 * *$ & $18.06 * *$ & $2.16^{\mathrm{ns}}$ \\
\hline & \multicolumn{5}{|c|}{ Green fruit } \\
\hline Late & $58.35 \mathrm{~B}$ & -18.56 & 35.65 & 40.22 & $117.50 \mathrm{~A}$ \\
\hline Early & $60.28 \mathrm{~A}$ & -16.54 & 37.34 & 40.09 & $116.55 \mathrm{~B}$ \\
\hline vc (\%) & 6.21 & 10.80 & 21.70 & 2.89 & 1.58 \\
\hline \multirow[t]{2}{*}{$\mathrm{F}$} & $6.86^{* *}$ & $3.42^{\text {ns }}$ & $1.29^{\text {ns }}$ & $0.35^{\mathrm{ns}}$ & $7.42 * *$ \\
\hline & \multicolumn{5}{|c|}{ Ripe fruit } \\
\hline Late & $67.73 \mathrm{~B}$ & 0.32 & 40.83 & 40.98 & 89.47 \\
\hline Early & $70.27 \mathrm{~A}$ & 0.31 & 42.07 & 42.02 & 89.76 \\
\hline vc (\%) & 6.13 & 10.80 & 9.27 & 10.02 & 5.76 \\
\hline \multirow[t]{2}{*}{$\mathrm{F}$} & $10.28 * *$ & $0.04^{\mathrm{ns}}$ & $3.01^{\mathrm{ns}}$ & $1.80^{\mathrm{ns}}$ & $0.09^{\text {ns }}$ \\
\hline & \multicolumn{5}{|c|}{ Green fruit } \\
\hline NB & $54.25 \mathrm{~B}$ & $-19.07 \mathrm{~A}$ & 34.94 & 39.84 & $118.60 \mathrm{AB}$ \\
\hline Pol blue 3+WFN & 55.46 B & $-19.42 \mathrm{~A}$ & 34.94 & 39.99 & $119.14 \mathrm{~A}$ \\
\hline Pol black 6+WFN & $57.32 \mathrm{~B}$ & $-18.13 A B$ & 39.69 & 39.95 & $117.34 \mathrm{BC}$ \\
\hline Pol black 8+WFN & $60.88 \mathrm{~A}$ & $-16.90 \mathrm{~B}$ & 36.19 & 40.53 & $116.51 \mathrm{C}$ \\
\hline Pol black $10+$ WFN & $61.52 \mathrm{~A}$ & $-15.38 B$ & 36.33 & 40.49 & $116.00 \mathrm{CD}$ \\
\hline Pol black10+Pol B & $63.36 \mathrm{~A}$ & $-16.73 \mathrm{~B}$ & 36.43 & 40.48 & $114.63 \mathrm{E}$ \\
\hline vc (\%) & 6.21 & 12.11 & 19.70 & 2.89 & 1.58 \\
\hline \multirow[t]{2}{*}{$\mathrm{F}$} & $18.41 * *$ & $1.35^{\mathrm{ns}}$ & $0.94^{\mathrm{ns}}$ & $1.21^{\mathrm{ns}}$ & $15.20^{* *}$ \\
\hline & \multicolumn{5}{|c|}{ Ripe fruit } \\
\hline NB & $66.70 \mathrm{~B}$ & $2.58 \mathrm{~A}$ & $44.74 \mathrm{~A}$ & $44.35 \mathrm{~A}$ & $86.40 \mathrm{~B}$ \\
\hline Pol blue 3+WFN & 66.65 B & $1.62 \mathrm{AB}$ & $43.16 \mathrm{AB}$ & $43.28 \mathrm{AB}$ & $87.53 \mathrm{AB}$ \\
\hline Pol black 6+WFN & $69.93 \mathrm{~A}$ & $-0.41 A B$ & 41.22 ABC & $41.96 \mathrm{ABC}$ & $90.74 A B$ \\
\hline Pol black 8+WFN & $69.81 \mathrm{~A}$ & $-0.31 A B$ & $40.13 \mathrm{BC}$ & $39.92 \mathrm{BC}$ & $90.51 A B$ \\
\hline Pol black $10+$ WFN & $70.30 \mathrm{~A}$ & -1.12 B & $41.21 \mathrm{ABC}$ & $41.50 \mathrm{ABC}$ & $91.76 \mathrm{~A}$ \\
\hline Pol black10+Pol B & $69.16 \mathrm{~A}$ & $-0.69 A B$ & $38.22 \mathrm{C}$ & $38.43 \mathrm{C}$ & $90.50 \mathrm{AB}$ \\
\hline vc (\%) & 6.13 & 10.80 & 9.27 & 10.02 & 5.76 \\
\hline $\mathrm{F}$ & $4.15^{*}$ & $3.11^{*}$ & $6.45^{* *}$ & $4.92 * *$ & $3.08 *$ \\
\hline
\end{tabular}

Means followed by the same letters in the column did not differ from each other by the Tukey test, $(p<0.05) .{ }^{*}, p<0.05 ;{ }^{* *}, p<0.01 ;{ }^{\text {Ns }}$, not significant to $F$ test $(p<0.05) . L^{*}$, brightness; $a^{*}$, coordinated a*; $b^{*}$ coordinated $b^{*} ; c^{*}$, chromaticity; $h^{\circ}$, hue angle. 
with Pol black 10+WFN and Pol black 10+Pol B (mild injury), while other treatments did not differ.

The reduction in LT with bagging affected the content of photosynthetic pigments and consequently fruit peel color (Tables 2 and 3). NB and Pol blue 3+WFN exhibited higher $\mathrm{Cl}$ index (severe injury) when compared with Pol black 10+WFN and Pol black $10+P o l B$, not differing from each other (Table 3). However, there was no interference of $\mathrm{LT}$ on $\mathrm{CL} b$. Hasan et al. (2000) observed that fruits protected with black polyethylene bags exhibited lower $\mathrm{CL} a$ content and higher $\mathrm{CL} b$ content compared to NB.

Bunches harvested in winter-spring showed higher $L^{*}, C^{*}$ and $h^{\circ}$ when green, and higher $L^{*}, b^{*}$ (yellow) and $C^{*}$ when ripe (Table 4). Therefore, they exhibited higher visual quality than fruits harvested in autumn-winter. L* (brightness). This is a color component that most decreases after the occurrence of $\mathrm{Cl}$. These results agree with the lower number of hours capable of causing stress (Table 1 ) and $\mathrm{Cl}$ index (2.13), which indicated mild damage, as compared estimates in autumn-winter (3.38), which indicated moderate damage (Table 3). The standard (desirable) color of fruits formed in the same experimental area in 2013 and 2014, in the absence of cold (summer), had mean $L^{*}$ value of $73.92 \%$, indicating larger deviations for fruits formed in autumnwinter $\left(\Delta \mathrm{L}^{*}=-7.96\right)$ than in winter-spring $\left(\Delta \mathrm{L}^{*}=-2.77\right)$. Early bagging promoted the harvest of fruits with higher $L^{*}$ and lower $\mathrm{h}^{\circ}$ (light green) (Table 4). The ripe bagged fruits showed peels with higher $L^{*}$. Green fruits bagged with Pol black $10+$ Pol B, Pol black 10+WFN and Pol black 8+WFN showed peel with higher $L^{*}$ and $a^{*}$, but with lower $h^{\circ}$, light green peel, compared to the other treatments (Table 4). After maturation, $L^{*}$ remained higher in fruits of these treatments. However, they also showed lower $b^{*}$ and $C^{*}$ and higher $\mathrm{h}^{\circ}$ values, denoting light yellow. Due to $\mathrm{Cl}, \mathrm{h}^{\circ}$ decreases and shifted towards the reddish region (Hashim et al. (2012), due to the discoloration of vascular strands (Chen et al., 2008). This is associated with the accumulation of oxidized polyphenols (Hashim et al., 2014). Harvey (2006) observed that reducing ST caused paler fruits before and after ripening. However, the increment of $7.6 \mu$ in the bag thickness did not result in increased yield or improved fruit color (Vargas-Calvo and Valle-Ruiz, 2011). The PHE content was higher in NB and Pol blue 3+WFN, which exhibited higher $\mathrm{Cl}$ index, followed by Pol black 8+WFN, Pol black $6+$ WFN, and Pol black 10+ WFN and Pol black 10+Pol B (Table 3). The PHE was associated with cold tolerance in two banana genotypes (El-Mahdy et al., 2018). During storage of banana at chilling T, Chen et al. (2008) detected increase in mRNA transcripts, phenylalanine ammonia-lyase (PAL) and protein levels, which is a key enzyme in the biosynthesis of various phenolic compounds. Although fruit bagging prevents PAL from being induced by sunlight, PHE synthesis is inhibited in the peel of various fruits (Sharma et al., 2014), which justifies its lower values in the peel of fruits of Pol black 10+WFN and Pol black10+Pol B treatments (Table 3). Bagging treatment with sunlight-impermeable, double-layer paper bags decreased the PHE content in peels of different apple cultivars (Chen et al., 2012).

In this study, we could not dissociate the effect of low $T$ and ST through the bag on the PHE content and color of green or ripe fruits. In addition, free phenolic compounds are consumed in oxidation reactions and subsequent polymerization (Nguyen et al., 2003) in banana subjected to post-harvest cold stress. Dissimilarly, fruits exposed to more cold stress, NB and Pol blue $3+$ WFN presented the highest levels (Table 3).

Regardless of bunch formation period and bagging time, significant and strong correlation between Tmin on the peel surface and $\mathrm{Cl}$ index $\left(r=-0.94^{*}\right)$ and $\mathrm{L}^{*}$ in green fruits $\left(r=0.78^{*}\right)$ was observed, indicating the effect of stress $T$ on the reduction of peel $L^{*}$, as well as PHE $\left(r=-0.92^{*}\right)$ and CAR contents $\left(r=-0.64^{*}\right)$.

Through the bagging material, ST was correlated with $\mathrm{Cl}$ index $\left(r=0.92^{*}\right), L^{*}\left(r=-0.77^{*}\right)$ and PHE $\left(r=0.85^{*}\right)$ in the peel of green fruits, confirming that fruits that received less sunlight showed higher $\mathrm{L}^{*}$, and lower $\mathrm{Cl}$ index and PHE content. There was positive correlation between $\mathrm{ST}$ and $\mathrm{CL} a$ $\left(r=0.59^{*}\right)$ and CAR contents $\left(r=0.67^{*}\right)$ on the peel of green fruits, showing that the synthesis of these pigments is related to sunlight availability. The correlation between PHE and $h^{\circ}$ in green $\left(r=0.60^{*}\right)$ and ripe fruits $\left(r=-0.46^{*}\right)$ indicates that higher the PHE content causes higher $h^{\circ}$ (more green), as opposed to the response observed in ripe fruits (less yellow). However, higher PHE content was correlated with lower $L^{*}\left(r=-0.81^{*}\right)$ in the peel of green fruits.

New experiments should be carried out to verify if: (1) the reduction of PHE in fruit peel with the use of material with low ST is an efficient measure to prevent cold damage on fruit peel; (2) the bag that prevents the transmission of long wavelength infrared during cold nights creates an insulating effect.

\section{Materials and methods}

\section{Experimental area}

The research was conduct at Univale farm, located at Jacupiranga, state of São Paulo, Brazil (24 24' 00" S latitude, 48 0 ' $00^{\prime \prime} \mathrm{W}$ longitude and $80 \mathrm{~m}$ above sea level). The climate of the region is classified as Af; tropical rainy without dry season (Alvares et al., 2013).

The soil is classified as Haplic Cambisol (Embrapa Solos, 2013), with 420,110 and $470 \mathrm{~g} \mathrm{~kg}^{-1}$ of clay, silt and sand, respectively. The $0-20 \mathrm{~cm}$ layer of the soil had the following characteristics: organic matter $(\mathrm{OM})=29 \mathrm{~g} \mathrm{dm}^{-3} ; \mathrm{pH}$ in water $=5.4 ; \mathrm{P}$ resin $=20 \mathrm{mg} \mathrm{dm}^{-3} ; \mathrm{K}, \mathrm{Ca}, \mathrm{Mg}$, potential acidity $(\mathrm{H}+\mathrm{Al})$, exchangeable acidity (Al) and cation exchange capacity (CEC) $\left(\right.$ mmolc $\left.\mathrm{dm}^{-3}\right)=1,30,10,40,0.1$ and 81.1, respectively; and base saturation $(\mathrm{V} \%)=50.68 \% ; \mathrm{S}, \mathrm{B}, \mathrm{Fe}$, $\mathrm{Mn}, \mathrm{Cu}$ and $\mathrm{Zn}\left(\mathrm{mg} \mathrm{dm}^{-3}\right)=10,0.3,207,17.5,1.5$ and 3.5.

\section{Plant material}

Planting was performed in 2013 in a density of 1600 plants ha $^{-1}$ using pest-free banana tissue-cultured plants (Musa spp. AAA group, Cavendish subgroup, cv. Nanica). In this research, we used inflorescences from $3^{\text {rd }}$ cycle of fruit production. All the cultural treatments necessary for good production were carried out.

\section{Experimental design}

The experimental design was a completely randomized design with eight replicates arranged in a $2 \times 2 \times 6$ factorial scheme, with two periods of bunch formation, two bagging times and six bag materials. 
The periods of bunch formation were autumn-winter (20/04/2015 to $14 / 08 / 2015)$ and winter-spring (31/07/2015 to $10 / 12 / 2015)$, coinciding, respectively, with the decrease of the $T$ in autumn and the elevation of the $T$ in spring. The bagging time was before of opening of the bracts (early) and after the complete opening, when all female hands were identified (late). The treatments were polyethylene bags with different thickness: blue transparent polyethylene $3 \mu+$ white non-woven fabric $3 \mu$ (Pol blue $3+W F N$ ), black polyethylene $6 \mu+$ white non-woven fabric $3 \mu$ (Pol black $6+$ WFN), black polyethylene $8 \mu+$ white non-woven fabric $3 \mu$ (Pol black $8+$ WFN), black polyethylene $10 \mu+$ white nonwoven fabric $3 \mu$ (Pol black 10+WFN) and black polyethylene $10 \mu+$ blue transparent polyethylene $5 \mu$ impregnated with bifenthrin insecticide (Biflex ${ }^{\circledR}$ ) (Pol black 10+Pol B) (Table 1). Non-bagged (NB) were used as the control.

In all plants, the flower, bracts and hands were removed and 8 hands bunch ${ }^{-1}$ were kept. $80 \mathrm{~g} \mathrm{ha}^{-1}$ of Imidacloprid was sprayed to control the tripes, except in the Pol black 10+Pol $B$. The bags were attached at the top of the bunch, on the stalk, and left open at the bottom.

\section{General assessments}

The temperature of the air in canopy and of the surface of fruits inside the bags were measured with copperconstantan thermocouples digitized in a data logger (Campbell Scientific, Logan, Utah, USA, Model CR 1000). T sensors were attached with adhesive tape to fruits of the median portion of bunch ( $4^{\text {th }}$ hand). Mean daily $T$ and cumulative rainfall were recorded at a meteorological station (Campbell Scientific, Logan, Utah, USA).

The fruit bunches were harvested when fruits from the last hand reached $3 \mathrm{~cm}$ in diameter. The $\mathrm{BM}$ and $\mathrm{PFH}$ were recorded. The $4^{\text {th }}$ hand was stored at $25^{\circ} \mathrm{C}$ and $85-95 \%$ relative humidity up to stage 6 of the Von Loeseck scale (1950).

\section{Assessed variables}

\section{$\mathrm{Cl}$ index}

The $\mathrm{Cl}$ was scored visually based on the intensity of surface browning according to the methodology of Nguyen et al. (2003) as follows: $1=$ no $\mathrm{Cl} ; 2=$ mild injury; $3=$ moderate injury; $4=$ severe injury; $5=$ very severe injury.

\section{Color of fruit peel}

It was measured at four locations around equatorial region on each fruit using a colorimeter (CR-400, Minolta, Tokyo, Japan). The illuminant was D65 and color was measured using the $\mathrm{CIE} L^{*} a^{*} b^{*}$ system. $L^{*}$ denotes brightness $(0=$ black and $100=$ white) and chromatic co-ordinates $a^{*}\left(+a^{*}=\right.$ green and $-\mathrm{a}^{*}=$ red $)$ and $b^{*}\left(+b^{*}=\right.$ yellow and $-\mathrm{b}^{*}=$ blue $)$. The hue angle $\left(\mathrm{h}^{\circ}=\tan ^{-1}\left[b^{*} / a^{*}\right]\right)$ and chromaticity $\left(\mathrm{C}^{*}=\left[\mathrm{a}^{*^{2}}\right.\right.$ $\left.\left.+b^{*^{2}}\right]^{1 / 2}\right)$ were calculated.

\section{Photosynthetic pigments}

Three peel discs were removed from one side of banana fruit and incubated with dimethyl sulfoxide for $24 \mathrm{~h}$ in the dark (Hiscox and Israelstam, 1979). The supernatant was used to determine the chlorophyll and carotenoid content according to Wellburn (1994), in a spectrophotometer Shimadzu UV1601.

\section{Total phenols content}

Frozen peel tissue were homogenized in ethanol and extraction was carried by $24 \mathrm{~h}$ in the dark. Then the homogenate was centrifuged at $12.000 \times \mathrm{g}$ for $20 \mathrm{~min}$ at $4^{\circ} \mathrm{C}$. The Folin-Ciocalteu method determined total phenols as described by Singleton et al. (1999). The quantification was conducted in a spectrophotometer Shimadzu UV-1601 and the results expressed as gallic acid equivalents in $\mathrm{mg} \mathrm{g}^{-1} \mathrm{FM}^{-}$ 1

\section{Statistical analysis}

Data of analyses were expressed as means of three replicate determinations. Statistical analysis was conducted with the SISVAR software (Ferreira, 2011). Mean comparisons were performed using the Tukey's test $(p<0.05)$. Correlation between variables was determinate by Pearson's coefficient. Plots in this paper were made by Origin 8.0.

\section{Conclusions}

The change of sunlight transmission with black polyethylene bags of different thickness did not promote significant increase in temperature and bunch mass, but reduced chilling injury and increased the peel brightness. On the other hand, late winter can increase fruit losses by sunburn. Although not controlling $\mathrm{Cl}$, early bagging is recommended to increase peel $L^{*}$.

\section{Acknowledgments}

The authors are grateful to FAPESP for the financial support (2012/01167-3 and 2015/04670-6), to Silvio Guatura Romão, José Carlos de Mendonça and José Alberto dos Santos for the technical support.

\section{References}

Al-Mahdouri A, Baneshi M, Gonome H, Okajima J, Maruyama $S$ (2013) Evaluation of optical properties and thermal performances of different greenhouse covering materials. Sol Energy. 96: 21-32.

Alvares CA, Stape JL, Sentelhas PC, Gonçalves JLM, Sparovek G (2013) Köppen's climate classification map for Brazil. Meteorol Z. 22: 711-728.

Chen JY, He LH, Jiang YM, Wanga Y, Joyce DC, Ji ZL, Lu WJ (2008) Role of phenylalanine ammonia-lyase in heat pretreatment-induced chilling tolerance in banana fruit. Physiol Plant. 132: 318-328.

Chen C, Zhang D, Wang Y, Li P, Ma F (2012) Effects of fruit bagging on the contents of phenolic compounds in the peel and flesh of 'Golden Delicious', 'Red Delicious', and 'Royal Gala' apples. Sci Hortic. 142: 68-73.

El-Mahdy MT, Youssef M, Eissa MA (2018) Impact of in vitro cold stress on two banana genotypes based on physiobiochemical Evaluation. S Afr J Bot. 119: 219-225.

Ferreira DF (2011) Sisvar: a computer statistical analysis system. Ciênc Agrotec. 35: 1039-1042. 
Embrapa Solos (2013) Sistema brasileiro de classificação de solos. Embrapa, Brasília.

Fortescue JA, Turner DW, Romero R (2011) Evidence that banana (Musa spp.), a tropical monocotyledon, has a facultative long-day response to photoperiod. Funct Plant Biol. 38(11): 867-878.

Harvey BV (2006) Mild chilling injury of banana (Cavendish cv. Williams) and its control in the field. PhD Thesis, University of Adelaide, Australia, September 2005.

Hashim N, Janius RB, Rahman RA, Osman A, Zude M (2012) Kinetic model for colour changes in bananas during the appearance of chilling injury symptoms. Food Bioprocess Tech. 5: 2952-2963.

Hashim N, Janius RB, Baranyai L, Rahman RA, Osman A, Shitan M, Zude M (2014) Changes of backscattering parameters during chilling injury in bananas. J Eng Sci Tech. 9: 314-325.

Hasan MA, Bhattacharjee S, Debnathv U (2000). Studies on the chlorophyll content of fruit peel during growth and development of banana (Musa AAA sub-group Cavendish, cv. Giant Governor) under different bunch covers. Orissa J Hortic. 28: 36-40.

Hiscox JD, Israelstam GF (1979) A method for the extraction of chlorophyll from leaf tissue without maceration. Can J Bot. 57: 1332-1334.

Jullien A, Chillet M, Malézieux E (2008) Pre-harvest growth and development, measured as accumulated degree days, determine the post-harvest green life of banana fruit. J Hortic Sci Biotechnol. 83: 506-512.

Kutinyu R, Fraiser C, Ngezimana W, Mudau FN (2014) Evaluation of banana bunch protection materials for optimum fruit production on cultivars grown in Mozambique. Trop Agr. 91: 109-115.

Lamont WJ (2017) Plastic mulches for the production of vegetable crops. In: Orzolek MD. A guide to the manufacture, performance, and potential plastics, 2nd edn. Willian Andrew, Oxford. 3.

Mangaraj S, Goswami TK, Giri SK, Tripathi MK (2009) Applications of plastic films for modified atmosphere packaging of fruits and vegetables: a review. Food Eng Rev. 1: 133-158.

Mustaffa MM, Kumar V (2012) Banana production and productivity enhancement. J Hort Sci. 7: 1-28.

Nguyen, T. B. T., Ketsa, S. and W. G. Van Doorn. (2003). Relationship between browning and the activities of polyphenol oxidase and phenylalanine ammonia lyase in banana peel during low temperature storage. Postharv Biol Technol. 30: 187-193.
Pathak P, Bhattacharyya RK, Baishya BK, Das U, Das J (2017) A review of works done regarding the impact of bunch cover application in banana. Int J Curr Microbiol Appl Sci. 6: 2181-2194.

Ravi I, Mustaffa MM (2013) Impact, adaptation and mitigation strategies for climate resilient banana production. In: Singh H, Rao N, Shivashankar K (eds) Climate-resilient horticulture: adaptation and mitigation strategies. Springer, India.

Rebouças PM, Dias IF, Alves MA, Barbosa Filho JAD (2015) Radiação solar e temperatura do ar em ambiente protegido. Rev Agrogeoambiental. 7: 115-125.

Sarkar S (2014) Shooting-harvest interval and physicochemical properties of banana (Musa AAA cv. Grand Naine) in relation to micro climate inside the bunch cover. Asian J Horti. 9: 40-42.

Santosh DT, Tiwari KN, Reddy RG (2017) Banana bunch covers for quality banana production - a review. Int J Curr Microbiol Appl Sci. 6: 1275-1291.

Sharma RR, Reddy SVR, Jhalegar MJ (2014) Pre-harvest fruit bagging: a useful approach for plant protection and improved post-harvest fruit quality - a review. J Hort Sci Biotech. 89: 101-113.

Simmonds NW (1962) The evolution of the bananas. Longman, London.

Singleton VL, Orthofer R, Lamuela-Raventos RM (1999) Analysis of total phenols and other oxidation substrates and antioxidants by means of Folin-Ciocalteu reagent. Methods Enzymol. 299: 152-178.

Vargas-Calvo A, Valle-Ruiz H (2011) Efecto de dos tipos de fundas sobre el fruto de banano (Musa AAA). Agron Mesoam. 22: 81-89.

Von Loesecke HW (1950) Bananas. 2nd edn. Interscience Publish Inc, New York.

Wellburn AR (1994) The spectral determination of chlorophyll $a$ and $b$, as well as total carotenoids, using various solvents with spectrophotometers of different resolution. J Plant Physiol. 144: 307-313.

Xu L, Huang B, Wu Y, Huang Y, Dong T (2011) The costbenefit analysis for bananas diversity production in China Foc. Zones. Am J Plant Sci. 2: 561-568.

Zapata LCR, Gil FLE, Martínez SC, May CRT, Marin FC, Fuentes G, Duch ES, Santamaría JM (2015) Preharvest foliar applications of glycine-betaine protects banana fruits from chilling injury during the postharvest stage. Chem Biol Technol Agric. 2: 4-10. 